\title{
Simulating the impact of pricing policies on residential water demand: a Southern France case study
}

\author{
Jean-Daniel Rinaudo*, Noémie Neverre*, and Marielle Montginoul ** \\ *BRGM (French Geological Survey), Water Department, 1034 rue de Pinville, 34000 \\ Montpellier, France.jd.rinaudo@brgm.fr \\ **Cemagref, 351 rue JF Breton, 34000 Montpellier, France.
}

\begin{abstract}
The case study conducted in this paper looks at residential water pricing from three different points of view. It first describes existing urban water-pricing practices in Southern France, emphasizing that pricing is not yet being used as a tool for providing economic incentives to save water. It then looks at the observed impact of pricing on water consumption, through an econometric analysis of a cross-sectional data set. The analysis suggests that demand, with an estimated price elasticity of -0.2 , is not yet very responsive to price variation. A regional water model (300 municipalities) is then developed and used to simulate the potential impact of various water-pricing scenarios on aggregate water demand, aggregate water sales revenue, and consumer surpluses. The results illustrate the trade-offs that have to be made between the search for environmental effectiveness, cost recovery, and equity when implementing complex water-pricing structures such as block rates or seasonal water pricing.
\end{abstract}

Keywords: demand elasticity, France, water pricing, residential water demand, simulation. 


\section{Simulating the impact of pricing policies on residential water demand: a Southern France case study}

\section{Introduction}

The abundant literature on residential water demand, summarized by (Espey et al. 1997, Arbues et al. 2003, Worthington and Hoffman 2008) suggests that price is a key determinant of demand. In Europe, policy makers increasingly hear this message. Water pricing is progressively being considered as a cost-effective measure for reducing imbalances between demand and available resources in water-poor areas. This development is reflected in the legal framework, in particular the Water Framework Directive (2000/60) which requires that by 2010 water-pricing policies should provide adequate incentives for consumers to use water resources efficiently (Article 9). The 1992 and 2006 French Water laws confirm this trend, by compelling Water Utilities to design tariffs which provide higher conservation incentives (environmental objective) while allowing water utilities to cover their costs (economic sustainability). One of the specific requirements of the 2006 law is that fixed charges should not exceed $30 \%$ of the average bill (i.e. a bill for $120 \mathrm{~m}^{3} /$ year).

To comply with this new regulatory framework, many Water Utilities will have to simultaneously reduce fixed charges and increase volumetric rates. Given that this change may have an undesirable social impact (Di Cosmo 2011), Water Utilities may consider using more complex tariff systems which, in theory, can simultaneously reduce demand, improve equity, and be revenue neutral. This is for instance the case for seasonal tariffs (ST), which consist of charging higher prices during the peak demand period, or increasing block tariffs (IBT), under which the marginal price increases with the quantity consumed (Hanemann 1998). In these two tariff systems, the rationale consists of imposing higher prices on users who generate a costly peak demand (e.g., users of second homes or owners of large homes with gardens and swimming pools). In the IBT case, social justice concerns can also be incorporated by making the initial volumes cheaper, the tariff being used to generate 
revenue-neutral cross-subsidies. Overall, both IBT and ST theoretically yield higher welfare benefits than the single-price policy (Krause et al. 2003).

Many studies have however shown that the impacts of such complex tariff are relatively complex. (Olmstead et al. 2007, Barberán and Arbués 2009, Barraque 2011). Practical implementation of IBT (e.g., choosing the block width and water-price levels) is still considered by water utilities to be a challenge, in view of the risk of unexpected financial or social impacts. This may explain why few French Utilities currently use IBT or ST - or when they do so, do not vary marginal price significantly (Montginoul 2007). There is thus an obvious need for simulation tools that can be used to assess the impacts of various rate structures and levels on water demand, revenues, and certain equity indicators.

While relatively sophisticated approaches have been developed to simulate ex-ante the impacts of various tariff systems (García-valiñas 2005), few of these approaches can easily be deployed by water professionals at the municipal, catchment, or regional level, without involving complex econometric analyses. Moreover, few simulation tools have been developed to simultaneously assess the impacts of tariff changes on water conservation, cost recovery, and equity indicators. This paper presents an attempt to fill this gap. Using a methodological approach inspired by (Jenkins et al. 2003), a model was developed which can easily be deployed at the catchment level. The originality of the approach lies in the scale at which the model is developed (i.e., several hundreds of municipalities). It also lies in its ability to account for the heterogeneity in municipal demand functions that result from differences in population income, housing characteristics, tourism-related activities, local climate, etc.

The research is based on a case study conducted in Southern France, in an area covering two river basins and one large aquifer (300 municipalities, area of $5000 \mathrm{~km}^{2}, 600,000$ inhabitants). Data used include secondary data provided by the National Statistical Institute (INSEE) and primary data (pricing, water use) collected through a field survey. Using a cross-sectional data set, an 
econometric analysis is first conducted to identify factors that explain variations in waterconsumption levels, including price level and structure. Average price elasticity is estimated using various functional forms. A simulation model is then constructed to simulate changes in water demand under several scenarios. The model enables testing of the impact of changes in price level and tariff structure (increasing block rate pricing, seasonal pricing). The remainder of this paper is organised as follows. Section 2 briefly describes the case study and provides an overview of the methodology. Section 3 describes the tariffs currently used by water utilities, and Section 4 presents the results of the econometric analysis. Simulation results depicting the impacts of various tariff scenarios are presented in Section 5. The paper concludes with a discussion of its policy implications.

\section{Case study and methodology}

\subsection{Case study presentation}

The analysis presented in this paper is part of a broader research study carried out over several years in a large coastal zone located in the Languedoc Roussillon region of France. The case study area encompasses 300 municipalities that draw on three major water resources: the Orb and Hérault rivers; the alluvial aquifers of these two rivers; and the Astian sand captive aquifer. The region is characterized by growing water needs mainly due to urban population growth and, to a lesser extent, to agricultural water needs. In previous work conducted in this geographic area the authors have estimated the future water deficit at 28 million cubic metres per year by 2020 (Rinaudo et al. 2010). This future water deficit is mainly attributed to urban development and the types of dwelling constructed (mainly detached houses with gardens and swimming pools). In this context, local policy-makers are looking for new resources to meet the growing water demand. Feasibility studies are currently being conducted to develop inter-basin transfers, use deep groundwater, and to install 
desalination plants. In parallel, there is a growing interest in water-demand management solutions, including reduction of leakages in distribution systems, water conservation and the use of incentive water pricing. The present study was initiated in this context. Its main objective was to estimate the reduction in water demand which could be achieved with incentive pricing systems.

\subsection{Methodology}

The work was carried out in three steps: (1) a survey of existing water tariffs; (2) an econometric estimation of price elasticity; (3) the development of a water-demand model and its application to simulate the impact of changes in water tariffs.

The survey of existing water pricing practices was implemented by using a survey methodology developed by (Montginoul 2007). A detailed questionnaire was mailed to all the Public Water Utilities, to collect information on water abstraction and sales, and water-pricing structure (e.g., flat rate, volumetric pricing, increasing block). The information collected was then incorporated into a regional database containing socio-economic information (e.g., type of housing, population characteristics, income level), climatic information (temperature and rainfall), and land use (indicator of urban density). Using a cross-section of data for the year 2005, a statistical model was then constructed to explain the differences observed in terms of water consumption per inhabitant, using a sub-sample of 137 municipalities (out of the 300) for which complete information was available.

The statistical model was estimated using the following form: $\log (\mathrm{C})=\alpha+\beta 1 . \log (\mathrm{p})+\beta 2 \cdot \log (\mathrm{I})+\beta \mathrm{i} . \mathrm{Xi}$, where $\boldsymbol{C}$ is the per capita annual water consumption ${ }^{1}, \boldsymbol{p}$ is the marginal price of water (for a $120 \mathrm{~m}^{3}$ water use), $\boldsymbol{I}$ the average municipal household income, $\boldsymbol{X} \boldsymbol{i}$ represents other explanatory variables such as local weather, density of second homes, etc. (additional details are provided in the next section), $\alpha$ is the intercept, and all $\beta$ i are estimated coefficients. The choice of a log-linear functional

\footnotetext{
${ }^{1}$ This average per capita water consumption is equal to the total volume of water sold to consumers divided by the population served. It therefore does not include water losses occurring in distribution system and which are on average equal to $30 \%$ in our case study area.
} 
form to describe the relationship between consumption on the one hand, and price and income on the other hand, is motivated by previous research where it was shown that elasticity can be considered to be constant and that it does not decrease along the demand curve (Gaudin et al. 2001). Also, as opposed to other functional forms, the log-log specification form facilitates interpretation of the coefficients as elasticity estimates, and enables direct comparisons with the existing literature.

In the third part of the work, a water-demand model is developed to simulate the impact of changes in price level and structures for the 300 municipalities in the case-study area. The methodology adopted is based on (Jenkins et al. 2003). A simple water-demand function is assumed, such that $\mathrm{C}=\mathrm{k} \cdot \mathrm{P}^{\xi}$, where $\mathrm{C}$ is water consumption ${ }^{2}, \mathrm{P}$ is the marginal water price, $\xi$ is the price elasticity, and $\mathrm{k}$ is a constant reflecting the structure of water use (e.g., differences in local climatic conditions and population income level). Our choice of this demand function is consistent with the choice of a loglinear functional form for the econometric analysis, and the assumption that price elasticity remains constant along the demand curve (Gaudin et al. 2001).

After calibrating the k parameter for each of the 300 municipalities, the impact of changes in waterprice levels and structures are simulated, taking into account their specific socio-economic characteristics (e.g., initial price level and proportion of detached houses). Simulations are carried out for price increase ranging from 0 to $2.5 € / \mathrm{m} 3$, using various tariff structures (simple proportional, increasing block rate, seasonal pricing). The model calculates three main output variables: variation in total water demand; change in consumer surplus; and variation in revenue from water charges for the Utility operating the distribution system. Note that calculations are performed separately for each municipality before aggregating the results and that the model only simulates water demand by consumers, without considering losses occurring in the distribution system which are assumed to be independent from tariffs implemented.

\section{Same definition as in foot-note 1.}




\section{Existing water-pricing practices}

In the area studied, the average price is $2.2 € / \mathrm{m}^{3}$, drinking water and sanitation charges included. This average price is calculated for a consumption of $120 \mathrm{~m}^{3} /$ year. It corresponds to the total bill for $120 \mathrm{~m} 3$ divided by 120 . This value is significantly lower than the national average $\left(3.1 € / \mathrm{m}^{3}\right)$, which can be explained by the fact that $17 \%$ of the municipalities do not have any wastewater treatment facility (no charge). As in in most French Water Utilities, bills are issued every six or twelve months. Water is charged on a volumetric basis in $99 \%$ of the municipalities (2 flat-rate cases only). On average, the fixed portion of the water bill represents $26 \%$ of the total water bill (for a $120 \mathrm{~m}^{3}$ consumption), but it exceeds $40 \%$ of the bill in $19 \%$ of the municipalities. A simple twopart tariff is used by $80 \%$ of the municipalities.

Increasing block pricing is used by $14 \%$ of the municipalities. The first block corresponds to a consumption of $80 \mathrm{~m}^{3}$ (median) - which is less than the average $120 \mathrm{~m}^{3}$ consumed by most households in a year. Other block widths are highly variable, but they are often quite large and designed to discriminate between residential, commercial, and industrial users. Table 1 below shows the prices charged for the various blocks, for the $14 \%$ of municipalities using increasing block tariffs. Block prices are significantly different: one cubic metre consumed in the $4^{\text {th }}$ block costs five times more than in the first block (drinking-water charge); however, the difference in price is less significant for wastewater treatment tariffs.

At the time of the survey (2007), decreasing block pricing was still used in $5 \%$ of the municipalities. However, the differences between prices charged for the various blocks are not significant: the average price is $0.82 € / \mathrm{m}^{3}$ for the first block and 0.58 for the last block. Moreover, the price generally decreases for very high consumption levels (250 to $500 \mathrm{~m}^{3}$ per year). This 
suggests that decreasing block pricing targets commercial activities, not households. It is mainly implemented where public utilities want to maximize water sales to recover heavy investment costs.

\section{Insert table 1 about here.}

\section{Factors determining the level of water consumption}

A statistical analysis was next conducted to estimate the impact of price on water demand, using cross-sectional aggregate data at the municipal level. The explained variable is the total volume of water sold in each municipality divided by the permanent population of the municipality. Industrial water sales are excluded, but sales to commercial activities, offices, hotels, and camping sites are included in the explained variable. The model was developed on the assumption that water consumption is determined by the following groups of factors:

- Population socio-economic characteristics (including income level, household size, proportion of households owning their housing, etc.).

- Urban characteristics (number of second homes, and proportion of population living in apartment buildings versus detached houses).

- Structure and level of water and sanitation tariffs (marginal price level, andpricing structure).

- Climate, which determines the intensity of garden-water needs: number of consecutive hot days (heat wave phenomena) and number of consecutive dry days (drought conditions).

- Whether consumers are allowed to drill a low-cost private well in order to substitute cheap untreated groundwater for municipal drinking water; the less expensive drilling is, the lower drinking-water consumption should be. For a description of the phenomenon in this part of France, see (Montginoul and Rinaudo 2011).

The primary data employed relate to price, water use, and estimates of the cost of drilling. The 
secondary data come from the national population census (INSEE, the National Statistical Institute) and the French Meteorological Institute (MeteoFrance).

The results of the econometric analysis (Table 3) show that the marginal price of water is a significant determining factor. Price elasticity is estimated at -0.18 which is well within the range of values reported in case studies in France (Nauges and Thomas 2003, Reynaud and Nauges 2010) or elsewhere in Europe (Espey et al. 1997, Arbues et al. 2003, Worthington and Hoffman 2008, Schleich and Hillenbrand 2009). This means that a $10 \%$ increase in price would result in a $1.8 \%$ decrease in water consumption. Other factors have the expected signs. As anticipated, water use is positively correlated with the cost of drilling a private borehole (the more expensive a borehole, the less people drill, and the more water they take from the mains). Water use is positively correlated with heat waves and drought indicators, and this relationship is statistically significant. The presence of second homes is also a key determining factor, and water consumption is higher for municipalities characterized by high income populations (income elasticity estimated at 0.42 ). Unexpectedly, the use of IBT does not have a statistically significant impact on water use. Also, the indicators do not provide evidence of a statistical relationship between water use and the ratio of single to multifamily housing units.

\section{Insert table 2 about here.}

\section{Insert table 3 about here.}

\section{Simulating the impact of changes in water pricing}

The simulation model presented in the second section was then implemented and used to simulate the impact of various water-pricing scenarios. The originality of the model developed resides in the scale at which it operates (calculation conducted at the municipal level, considering their specific characteristics) and the types of results it delivers. It not only estimates changes in water 
consumption but also calculates changes in revenues for the public water utility, and variations of consumer surplus for four main types of households. The information obtained can thus be used to assess various scenarios in terms of environmental effectiveness, cost recovery, and equity.

Several water-pricing scenarios are simulated. The various curves in Figure 1 show the simulated variation of total water demand (in $\mathrm{m}^{3}$ ) in the 300 municipalities for various price level increases ranging from 0 to $+2.5 € / \mathrm{m}^{3}$ (horizontal axis) and for various pricing structures (separate curves). The first scenario (curve 2PARTS on Figure 1) simply consists of increasing the volumetric price by a fixed amount (ranging from 0 to $2.5 € / \mathrm{m}^{3}$ ), which consumers have to pay on top of the existing price in each municipality. Given that the objective is solely the reduction of water consumption, the extra revenue generated by the price increase is redistributed to consumers through a reduction in the fixed charge. Figure 1 shows that an increase of $1 € / \mathrm{m}^{3}$ (corresponding to a $50 \%$ increase in the current marginal price) would reduce total regional demand by approximately 3 million cubic meters per year - the equivalent of 20,000 households or 48,000 inhabitants. Given that approximately 8,400 new inhabitants migrate into the case-study area each year, this would allow a 6-year postponement of the costly investments needed to mobilise new water resources. This clearly illustrates an additional benefit of water conservation which is rarely highlighted in the literature (Kanakoudis et al. 2011).

The second scenario consists of increasing the volumetric water price during the summer period only (curve SEASONAL). Note that although the reduction in water demand is smaller than in the first scenario, it occurs in summer when water resources are limited and demand is at its maximum level. Moreover, this seasonal pricing system is theoretically more cost-effective, since it does not impact the consumer surplus in winter when water is plentiful, and operates only when water demand is at a maximum and water resources are limited. Moreover it improves equity by increasing the relative contribution of seasonal residents (owners of second homes, tourists), who are responsible for additional investment costs but rarely pay for them under a uniform annual water 
price.

\section{Insert figure 1 about here}

Figure 2 below illustrates how the model can be used to assess the impact of water-pricing scenarios for various types of household separately. The main types considered are temporary residents (second homes); households in apartment buildings (with and without individual water meters); and households in detached houses (with or without gardens). Figure 2 shows how an increase in the price level (with a two-part tariff) affects the total demand of consumers in detached houses with and without gardens. The curves shown in Figure 2 are based on calculations performed at the municipal level, taking into account the proportion of each type of housing, before regional aggregation. Figure 2 clearly shows that households occupying single-family houses (with gardens) are the most affected. Similarly, welfare changes are estimated for various types of households, using the consumer economic surplus as a measure of well-being. Figure 3 shows the variation of economic surplus for several types of consumers, assuming a seasonal tariff is implemented and progressively raised (summer price surcharge of 0 to $2.5 € / \mathrm{m}^{3}$, compensated by a reduction of the price in winter). For instance, adding a surcharge of $1 € / \mathrm{m}^{3}$ in summer would reduce by 40 $€ /$ household per year the economic surplus of households occupying single family houses, versus only 15 to $20 €$ for other types of consumers. One may consider this to be a desirable social impact, since it leads to an increased financial contribution from households generating extra investment costs for the peak-demand period.

\section{Insert figure 2 about here}

\section{Insert figure 3 about here}

The model is then used to simulate the complex impacts of IBT. Several IBT scenarios are considered, all assuming a three-block system. The first block ranges from 0 to $50 \mathrm{~m}^{3}$, the second 
block from 51 to $100 \mathrm{~m}^{3}$ and the third block more than $100 \mathrm{~m}^{3}$. Each water-pricing scenario is described by three values $(a, b, c)$, where $a$ is the price increase for the first block, $b$ the price increase for the second block, and c the price increase for the third block. The three block prices are then varied to achieve different objectives:

- In scenario $(0,0, X)$, the price is unchanged for the first two blocks and increased by $\mathrm{X}$ for the third block (X being varied from 0 to $2.5 € / \mathrm{m}^{3}$ ). The objective of this scenario is to penalise water uses above $100 \mathrm{~m} 3 /$ year, which mainly correspond to outdoor uses (garden irrigation and swimming pools).

- In scenario $(0, X, X)$, the price is unchanged for the first block (for social reasons) but progressively increased by $\mathrm{X} € / \mathrm{m}^{3}$ for the second and third blocks. This scenario aims to promote water conservation indoors (toilet flushes and appliances) as well as outdoors.

- Scenario $(0, \mathrm{X} / 2, \mathrm{X})$ is a progressive scenario: the first block is unchanged, the second increases by $X / 2 € / \mathrm{m}^{3}$ (targeting indoor uses), and the third by $X € / \mathrm{m}^{3}$ (targeting outdoor uses).

- In the last scenario $(-\mathrm{X} / 5,0, \mathrm{X})$, the price of the first block is reduced by $\mathrm{X} / 5 € / \mathrm{m}^{3}$ (i.e., first block subsidised at a $20 \%$ rate), the second block is unchanged, and the third block is increased by $\mathrm{X} € / \mathrm{m}^{3}$ (collection of additional revenue to offset the first-block subsidy).

The resulting effect on aggregate water demand is depicted in Figure 4. The curves shown on this figure are constructed by varying $X$ from 0 to $2.5 € / \mathrm{m}^{3}$. They show, for instance, that if an increase of $1 € / \mathrm{m}^{3}$ is applied with a $(0,0, \mathrm{X})$ structure, water demand will decrease by 2.3 million cubic metres. If a $(0, X, X)$ structure is applied, this $1 € / \mathrm{m}^{3}$ price increase will reduce total water demand by 3 million $\mathrm{m}^{3}$. Overall, Figure 4 shows that for a reasonable price increase $\left(X=1 € / \mathrm{m}^{3}\right)$, the various scenarios will yield relatively similar water conservation effects (between 2.7 and 3.5 million $\mathrm{m}^{3}$ per year). For a higher price increase $\left(X=2 € / \mathrm{m}^{3}\right)$, the difference becomes significant (from 3 to 4.5 
million m3).

\section{Insert figure 4 about here.}

By contrast, the effects on aggregate revenues differ drastically. Figure 5 clearly shows, for instance, that the choice of a $(0, X, X)$ pricing structure will increase revenue. The same conclusion applies to $(0, \mathrm{X} / 2, \mathrm{X})$. Interpreting the results for the two other scenarios is more complex. For instance, the reason why $(0,0, \mathrm{X})$ leads to a reduction of income is because a number of large users are shifting from the third to the second block. In this case the loss of volume sold in the last block is not offset by the increase in price of this last block. Similarly, the $(-\mathrm{X} / 5,0, \mathrm{X})$ scenario generates huge financial losses for the Water Utilities. Indeed, while all consumers are being subsidised for their first block (50 $\mathrm{m}^{3} /$ year/household), only a few large consumers generate additional income due to the increase in the last block. Moreover, many large consumers shift from the last to the second block - whose price is unchanged. Overall, these results show the complexity of predicting the revenue impact of using IBT, at the aggregate regional level.

\section{Insert Figure 5 about here.}

The various water-pricing scenarios simulated above are compared, assuming an increase in $\mathrm{X}$ of 1 $€ / \mathrm{m}^{3}$. Table 4 shows that an increase of $1 € / \mathrm{m}^{3}$ can yield a reduction of water demand ranging from 1.6 to 3 million $\mathrm{m}^{3}$ per year. Keeping in mind that within our case-study area the anticipated 2020 water deficit will be about 28 million $\mathrm{m}^{3}$, these simulation results show that water pricing is probably part of the solution - but not a complete solution- for the future water crisis. Other actions will in any event have to be undertaken, including reduction of leakages in distribution networks, the promotion of water-conservation actions, and the mobilization of new water resources.

Table 4 also shows that increasing $\mathrm{X}$ by $1 € / \mathrm{m}^{3}$ may have contrary effects on the budgets of water utilities, depending on which tariff structure is selected. Two block tariffs $(0,0, \mathrm{X}$ and $(-\mathrm{X} / 5,0, \mathrm{X})$ 
lead to budget deficit situations. All the other scenarios will generate excess revenues which could either be used to reduce the fixed portion of the water bill for all consumers, or reinvested in waterconservation programs.

\section{Insert Table 4 about here.}

\section{Discussion and conclusion}

The results of this study illustrate that the choice of a water-pricing structure is a complex exercise, involving trade-offs between cost recovery, equity, and environmental efficiency. The simulation tool presented in this paper can be helpful in understanding this trade-off and in exploring the various impacts of alternative scenarios. The main advantage of this model lies in the scale at which it can be implemented (river basin) and its ease of implementation by water managers and planners, without involving the use of complex econometric techniques.

From a policy perspective, the results of our simulations confirm previous findings concerning the use of IBT as a redistributive tool. Cross subsidies between blocks will most likely cause cost recovery problems. To avoid such problems, more sophisticated IBTs have been considered by scholars and practitioners, including for instance option tariffs specifically designed to reduce the bills of large families (Barberán and Arbués 2009) or the use of per capita IBTs as already practiced by many water utilities in Southern California. It is however often recommended that social issues should be addressed "outside the water bill", as already suggested by both academic authors (Barraque 2011) and practitioners (AWWA 2004).

From a methodological perspective, our simple modelling approach is characterised by a number of assumptions which can be debated. The first problematic assumption is that price elasticity values remain valid outside the price range within which they were estimated. Results from empirical studies suggest that this may not be the case. In their meta-analysis of price elasticity, (Espey et al. 1997) have shown that elasticity values reported in case studies are positively correlated with price 
levels and that they can be influenced by the pricing structure used, climate, and other factors. However, given the difficulty of predicting future changes in price elasticity, the authors recommend the adoption of a conservative assumption, e.g.,. keeping elasticity constant, as in our own case study.

The second debatable assumption is that households perfectly understand their rate structure and respond to marginal price changes. This has been challenged by (Nieswiadomy 1992) and by later studies showing that the mere existence of IBT can reduce demand, irrespective of the change in price level (Kenney et al. 2008). Other studies have also shown that price response was positively correlated with households' level of information concerning tariffs. As an illustration, one American study found that a utility that provides detailed tariff information on its water bill can attain the same level of conservation with a 30 to $40 \%$ lower rate increase (Gaudin 2006). The model presented in this study can clearly not account for this effect of information and awarenessraising programs, thus probably underestimating the water-conservation effect of water-pricing policies.

The third caveat regarding our modelling approach is that it does not account for the possibility that households may develop alternative water sources, such as gray water recycling, rainwater harvesting, or private borehole drilling in response to tariff increases. This trend is already being observed in many industrialised countries such as France (Montginoul and Rinaudo 2011), Australia (Hurlimann 2011), and Belgium (AQUAWAL 2010) among other countries. Indeed, an increased marginal price is likely to provide significant incentives for large consumers to invest in such alternative, decentralized water-supply systems, as shown by (Montginoul and Rinaudo 2011) in the case of private boreholes in France. However, if some consumers quit or use less, then others will have to pay more, since all consumers are bound together by the heavy fixed cost of infrastructure (Barraque). This shows the need for more comprehensive modelling approaches that will account for the possibility of resource substitution- a new area of research which the authors 
are currently investigating.

\section{References}

AQUAWAL. 2010. Etude relative à l'ilmpact sur les usagers des réformes en matière de tarification de l'eau et à l'estimation de l'emploi généré par le cycle anthropique de l'eau en Wallonie. AQUAWAL (Association of Walloon Water Supplies), Namur.

Arbues, F., M. A. Garcia-Valinas, and R. Martinez-Espineira. 2003. Estimation of residential water demand: a state-of-the-art review. Journal of Socio-Economics 32:81-102.

AWWA. 2004. Thinking outside the bill: a utility manager's guide to assisting low income water custommers. American Water Works Association, Denver.

Barberán, R., and F. Arbués. 2009. Equity in DomesticWater Rates Design. Water Resources Management 23:2101-2118.

Barraque, B. 2011. Is individual metering socially sustainable? The case of multifamiliu Housing in France. Water Alternatives 4:223-244.

Di Cosmo, V. 2011. Are the Consumers Always Ready to Pay? A Quasi-Almost Ideal Demand System for the ItalianWater Sector. Water Resources Managemnt 25:465-481.

Espey, M., J. Espey, and W. D. Shaw. 1997. Price elasticity of residential demand for water: A meta-analysis. . Water Resources Research 33 1369-1374.

García-valiñas, M. 2005. Efficiency and Equity in Natural Resources Pricing: A Proposal for Urban Water Distribution Service. Environmental and Resource Economics 32:183-204.

Gaudin, S. 2006. Efect of price information on residential water demand. Applied economics 38:383-393.

Gaudin, S., R. C. Griffin, and R. C. Sickles. 2001. Demand Specification for Municipal Water Management: Evaluation of the Stone-Geary Form. Land Economics 77:399-422.

Hanemann, W. M. 1998. Price and rate structure. Pages 137-179 in B. D.D., B. J.J., and H. W.M., editors. Urban Water Demand Management and Planning. Mc Graw Hill, New-York.

Hurlimann, A. 2011. Household use of and satisfaction with alternative water sources in Victoria Australia. Journal of Environmental Management 92:2691-2697.

Jenkins, M. W., J. R. Lund, and R. E. Howitt. 2003. Using economic loss functions to value urban water scarcity in California. Journal of American Water Works Association 95(2): 58-70.

Kanakoudis, V., K. Gonelas, and D. Tolikas. 2011. Basic principles for urban water value assessment and price setting towards full-cost recovery - pinpointing the role of the water losses. Journal of Water Supply: Research and Technology - AQUA 60:27-39.

Kenney, S. D., C. Goemans, R. Klein, J. Lowrey, and K. Reidy. 2008. Residential water demand management: lessons learnt from AUrora, Colorado. Journal of the American Water Resources Association 44:192-207.

Krause, K., J. M. Chermak, and D. S. Brookshire. 2003. The Demand for Water: Consumer Response to Scarcity. Journal of Regulatory Economics 23:167-191.

Montginoul, M. 2007. Analysing the Diversity of Water Pricing Structures: The Case of France. Water Resources Management 21:861-871.

Montginoul, M., and J.-D. Rinaudo. 2011. Controlling households' drilling fever in France: An economic modeling approach. Ecological Economics 71:140-150.

Nauges, C., and A. Thomas. 2003. Long-run Study of Residential Water Consumption. Environmental and Resource Economics 26:25-43.

Nieswiadomy, M. L. 1992. Estimating urban residential water demand: Effects of price structure, conservation, and education. Water Resources Research 28:609-615.

Olmstead, S. M., W. Michael Hanemann, and R. N. Stavins. 2007. Water demand under alternative price structures. Journal of Environmental Economics and Management 54:181-198.

Reynaud, A., and C. Nauges. 2010. How much water do residential users really need ? An 
estimation of minimum water requirements for French households. Pages 24 in Paper presented at the World Congress of Environmental and Resource Economists, Montreal, Canada.

Rinaudo, J. D., M. L, and Y. Caballero. 2010. Cost-effectiveness analysi of a water scarcity management plan: considering long term and climatic change. Pages 183-190 in CIHEAM, editor. Economics of Drought and drought preparedness in a climate change context, Paris. Schleich, J., and T. Hillenbrand. 2009. Determinants of residential water demand in Germany. Ecological Economics 68:1756-1769.

Worthington, A. C., and M. Hoffman. 2008. An Empirical Survey of Residential Water Demand Modelling. Journal of Economic Surveys 22:842-871. 


\section{Tables}

Table 1: Drinking Water (DW) and Wastewater Treatment (WWT) price levels for municipalities using Increasing Block Tariff (in $€ / \mathrm{m}^{3}$, all taxes included).

\begin{tabular}{lcccc} 
& $\begin{array}{c}\text { 1st block } \\
\text { price }\end{array}$ & $\begin{array}{c}2^{\text {nd }} \text { block } \\
\text { price }\end{array}$ & $\begin{array}{c}3^{\text {rd }} \text { block } \\
\text { price }\end{array}$ & $\begin{array}{c}4^{\text {th }} \text { block } \\
\text { price }\end{array}$ \\
\hline Increasing block (DW) & 0.23 & 0.55 & 0.8 & 1 \\
Increasing block (WWT) & 0.25 & 0.35 & 0.38 & - \\
\hline Decreasing block (DW) & 0.82 & 0.66 & 0.62 & 0.58 \\
Decreasing block (WWT) & 1.05 & 0.95 & - & - \\
\hline
\end{tabular}

Table 2 Main dependent variables included in the statistical analysis of water demand.

\begin{tabular}{ll}
\hline \multicolumn{1}{c}{ Name } & \multicolumn{1}{c}{ Description } \\
\hline MARGINAL_PRICE & $\begin{array}{l}\text { Marginal price paid by the consumer (for a consumption of } 120 \mathrm{~m}^{3} \text { ) } \\
\text { including drinking-water and sewerage charges }\end{array}$ \\
\hline INCOME & Average taxable income per inhabitant (calculated at municipal level) \\
\hline DRILL_COST & $\begin{array}{l}\text { Estimated investment cost (in } € \text { ) of drilling a well for domestic water } \\
\text { (considering geological characteristics of each municipality) }\end{array}$ \\
\hline TEMPERATURE & Number of days from May to August when temperature exceeds $28^{\circ} \mathrm{C}$. \\
\hline DRY_DAYS & Total number of dry days in a year \\
\hline SECOND_HOMES & $\begin{array}{l}\text { Number of second homes (used only for holidays and weekends) in the } \\
\text { municipality, divided by number of permanent inhabitants }\end{array}$ \\
\hline DETACHED_HOUSES & Proportion of detached houses in total housing \\
\hline
\end{tabular}

Table 3 Results of the best reduced econometric model (linear regression). Explained variable $=\log$ (consumption in $\mathrm{m}^{3}$ per inhabitant).

\begin{tabular}{|c|c|c|c|c|}
\hline Variable & \multicolumn{2}{|c|}{ Coefficient } & \multicolumn{2}{|c|}{ Model statistics } \\
\hline Log MARGINAL PRICE & -0.18 & & & \\
\hline $\log ($ INCOME) & 0.42 & $* * *$ & Number of & \\
\hline DRILL_COST & 0.00002 & $* * *$ & observations: & 137 \\
\hline TEMPERATURE & 0.12 & $* * *$ & Adjusted $\mathrm{R}^{2}$ & 0.4521 \\
\hline DRY_DAYS & 0.009 & *** & Fisher & 0.0000 \\
\hline SECŌND HOMES & 0.4 & *** & Link Test & 0.28 \\
\hline DETACHED_HOUSES & -0.45 & *** & White Test & 0.6825 \\
\hline Constant & 0.4 & & & \\
\hline
\end{tabular}

Table 4: Effect of increasing $X$ by $1 € / \mathrm{m}^{3}$ for 6 different tariff structures.

\begin{tabular}{|c|c|c|c|c|c|c|}
\hline Water-pricing scenario & $\begin{array}{c}\text { Seasonal } \\
\text { pricing }\end{array}$ & $\begin{array}{c}\text { Block } \\
(\mathbf{X}, \mathbf{X}, \mathbf{X})\end{array}$ & $\begin{array}{c}\text { Block } \\
(0,0, X)\end{array}$ & $\begin{array}{c}\text { Block } \\
(\mathbf{0}, \mathbf{X}, \mathbf{X})\end{array}$ & $\begin{array}{c}\text { Block } \\
(0, X / 2, X)\end{array}$ & $\begin{array}{c}\text { Block } \\
(-\mathrm{X} / \mathbf{5}, 0, \mathrm{X})\end{array}$ \\
\hline Water demand reduction $\left(\mathrm{M} \mathrm{m}^{3}\right)$ & 1.6 & 3 & 2.3 & 3 & 2.6 & 2.3 \\
\hline
\end{tabular}




\begin{tabular}{lllllll}
\hline Water sales revenue variation $(\mathrm{M})$ & +12.5 & +38 & -4 & +10 & +3.5 & -10 \\
\hline
\end{tabular}

\section{Figures}

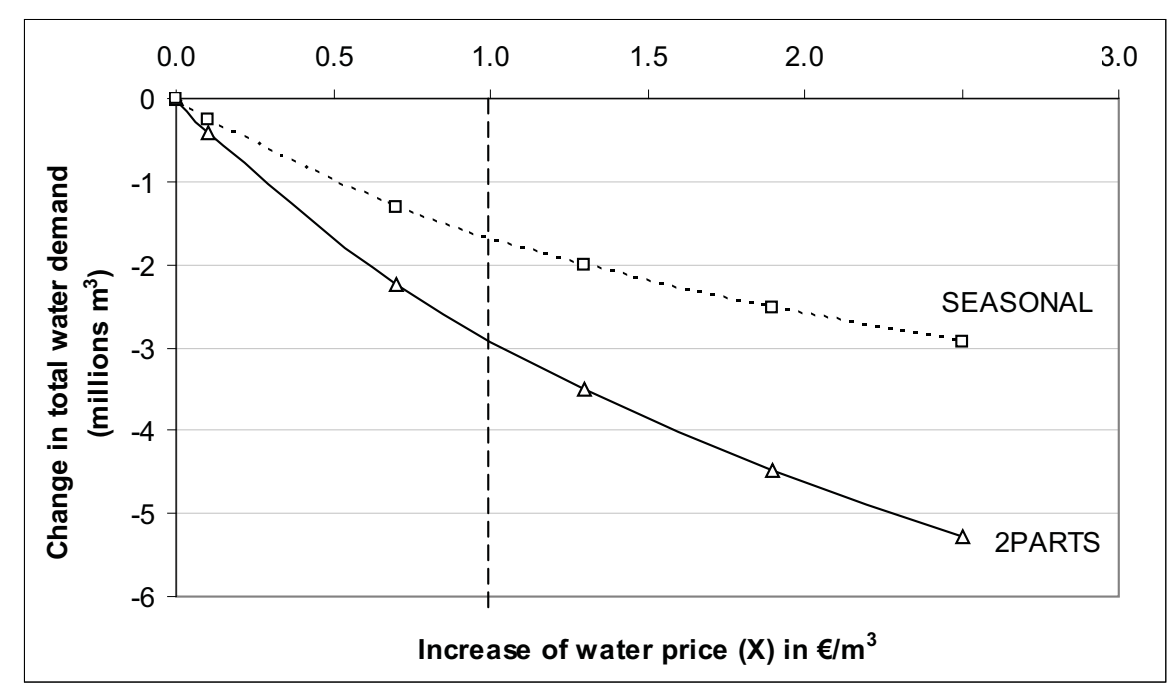

Figure 1: Simulated variation of total water demand (300 municipalities) for various price level increase and alternative tariff structures.

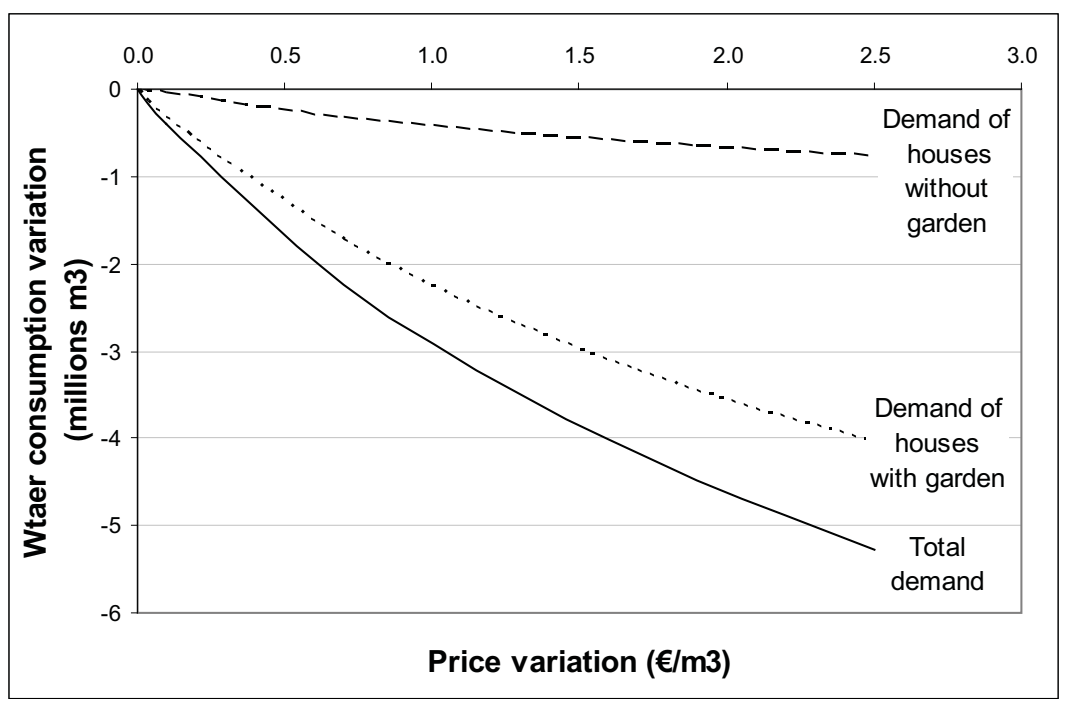

Figure 2: Variation of total water demand (300 municipalities) of consumers in houses with and without gardens in response to a two-part increase of water price. 


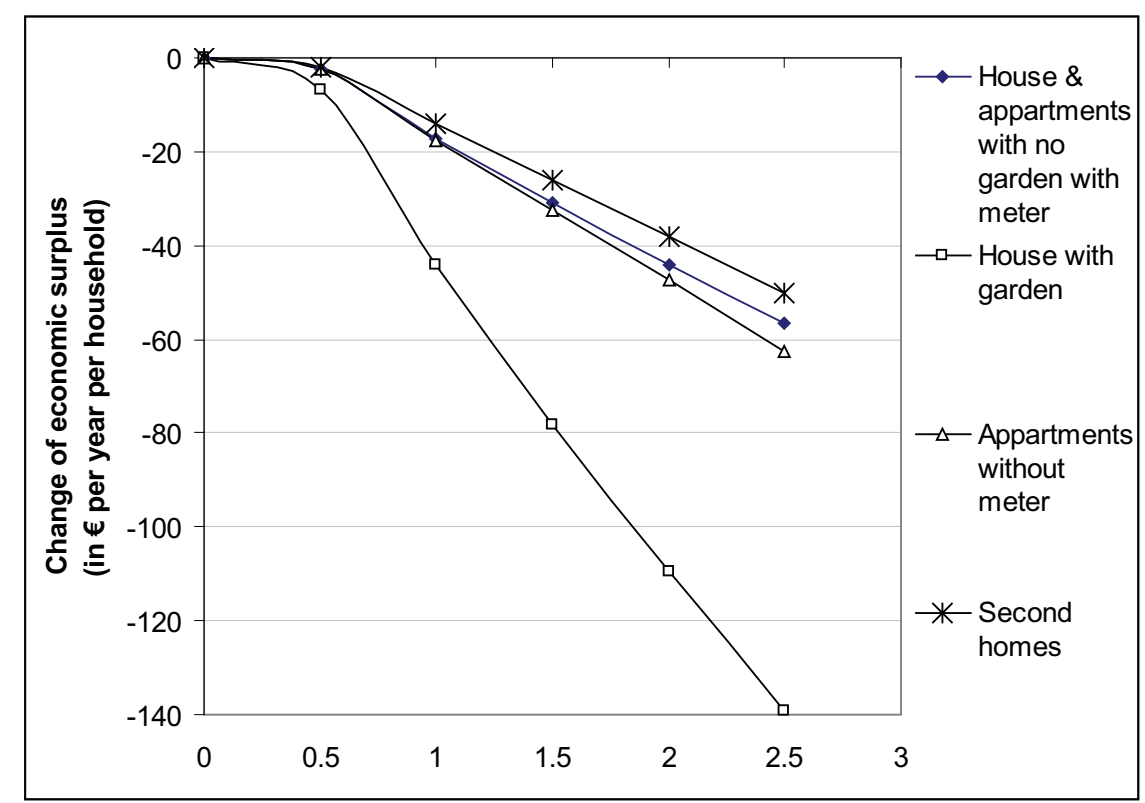

Figure 3 Variations in Consumer surplus for various types of households with a seasonal increase of water price.

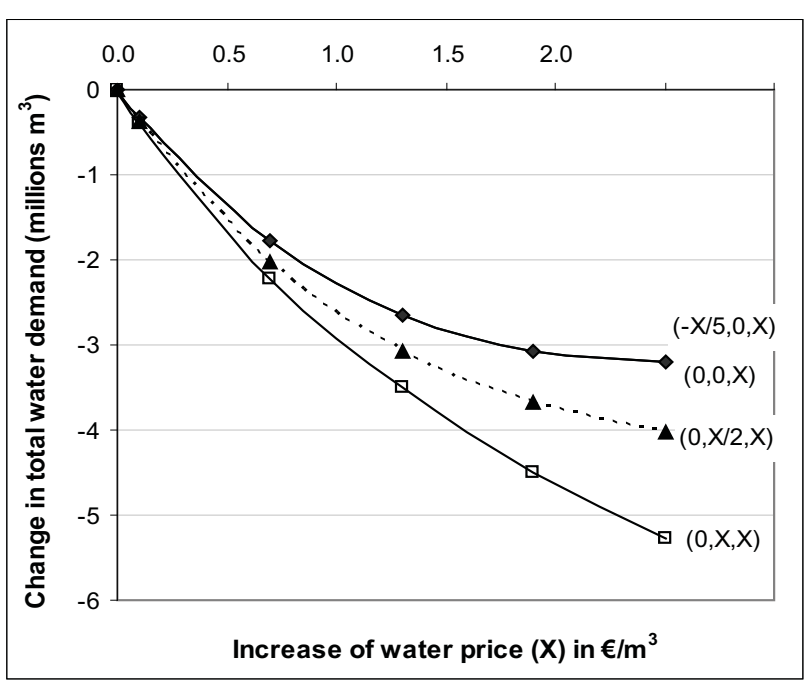

Figure 4: Impact of various block pricing scenarios on aggregate water demand (300 municipalities). Curve corresponding to scenario $(-\mathrm{X} / 5,0, \mathrm{X})$ is identical to $(0,0, \mathrm{X})$.

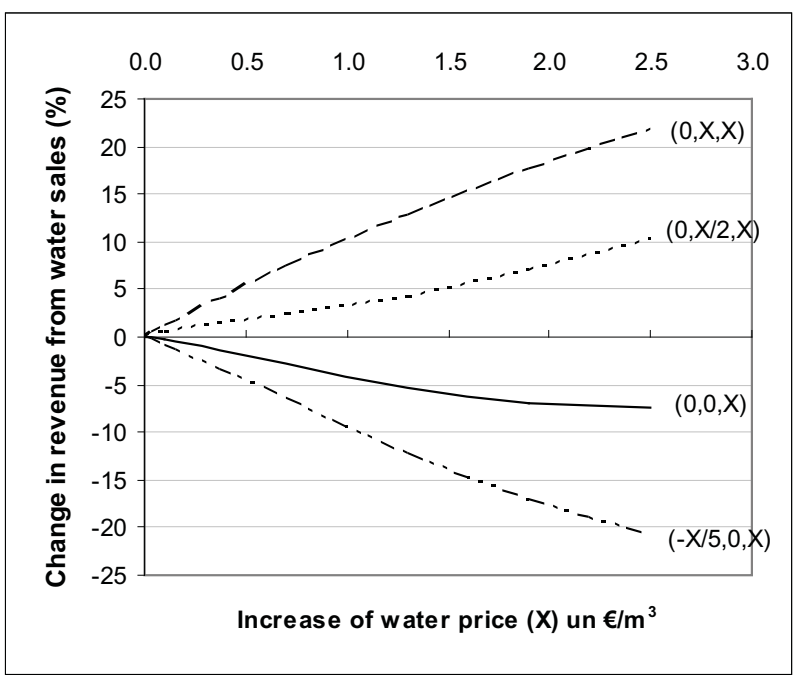

Figure 5: Variation of water sales revenue under various block pricing structures. 